\title{
EOQ "93" Maailman laatukonferenssi aikuiskoulutuksen näkökulmasta tarkasteltuna
}

\author{
"Koulutusinstituutioiden \\ kehittäminen laatujohtamisen \\ näkökulmasta merkitsee sitä, että \\ oppimisprosessia tarkastellaan \\ instituution keskeisimpänä \\ toimintaprosessina."
}

Euroopan laatujärjestö (EOQ eli European Organization for Quality) järjesti kansainvälisen laatualan kongressin viime kesänä 15.-17. päivänä kesäkuuta Helsingissä. Kongressiin osallistui noin 1000 henkilöä. Heistä 700 oli kotoisin yli 30:sta eri maasta. Suomalaisia osallistujia oli noin 300. Aikuiskoulutuksen kannalta kongressi oli mielenkiintoinen seuraavista syistä:

Koulutuksen laatuun liittyvät kysymykset kiinnostavat yhä enemmän koulutuksen järjestäjiä.

Laatu on käsitteenä monitulkintainen, jolloin kansainvälinen kongressi voi antaa hyvän mielikuvan erilaista tavoista tarkastella tätä käsitettä.

Koulutusinstituutioiden johtoa on yhä enemmän alkanut kiinnostaa virallisen hyväksynnän saanti sille, että niiden toiminta täyttää kansainvälisen laatustandardin.

Korkean laadun tavoittelussa aikuiskoulutuksen ja aikuiskasvatuksen kysymyksin joudutaan paneutumaan entistä enemmän myös elinkeinoelämän alueella.

Kongressissa oli koko ajan meneillä viisi rinnakkaista istuntoa. Yhtenä päivänä eräs istunnoista keskittyi laatukoulutuksen ja kasvatuksen kysymyksiin ("Quality training and education"). Laadun tekemiseen liittyviä inhimillisiä näkökohtia tarkasteltiin useissa istunnoissa, esimer- kiksi istunnossa, jonka nimenä on "Human aspects of quality". Korkeakoulussa työskentelevää kiinnosti istunto, jonka nimenä oli "Quality in research and development".

Kasvatustieteellisiin kongresseihin tottuneen näkökulmasta esitykset olivat didaktisesti ja teknisesti korkeatasoisia eikä tuhruisia pikku piperrystä sisältäviä kalvoja näkynyt. Kongressiesitelmät jaettiin kolmeksi kirjaksi sidottuna heti kongressin alussa. Päällimmäiseksi mielikuvaksi jäi, että kasvatusalan ihmisinä voisimme ottaa oppia kongressin esitelmöitsijöistä.

\section{Laatu-käsitteestå}

Laatu-käsitettä tulkitaan eri tavoin myös asiantuntijapiireissä. Sillä voidaan tarkoittaa yhtä tai useampaa kohtaa seuraavasta vaihtoehdoista:

- kyse on virheettömästä tuotteesta tai palvelusta,

- kyse on suorituskykyisestä tuotteesta tai hyvin toteutetusta palvelusta,

- kyse on siitä, että saadaan paras vastine tuotteeseen tai palveluun sijoitetulle rahamärälle,

- kyse on siitä, että tuote tai palvelu on vähintäänkin yhtä hyvä kuin kilpailijoiden tarjoama,

- kyse on siitä, että laatu on mitä tahansa asiakas haluaa, jolloin asiakkaan tyytyväisyys ratkaisee, 
— kyse on siitä, että hyvä tuote tai palvelu aiheuttaa mahdollisimman vähän ympäristöhaittaa.

Yhä enemmän näyttää yleistyvän kokonaisvaltaisen laatujohtamisen (Total quality management) sisältämä käsitys laadusta. Sen mukaan hyvän laadun tulee sisältää kaikki edellä kuvatut tunnusmerkit.

Koulutusalan kirjallisuudessa laadun käsitettä ei useinkaan tarkemmin määritellä tai sitten se nähdään hyvin rajoitetusti esim. siten, että kyse on esimerkiksi vain asiakkaan tyytyväisyydestä. Valmistavan teollisuuden ja palveluyritysten toiminnan yhteydessä kehitettyjä laatuun liittyviä käsitteitä joudutaan kriittisesti arvioimaan, kun niitä käytetään aikuiskoulutuksen yhteydessä. Esimerkiksi käsite "asiakas" on varsin moniulotteinen asia vaikkapa nuorisoasteen ammatillisesta koulutuksesta puhuttaessa.

Kansainvälisessä kongressissa on myös mielenkiintoista tarkastella miten asioita painotetaan eri maissa. Esimerkiksi japanilaiset korostavat sitä, että laatua kehitettäessä jokainen työntekijä on saatava mukaan prosessiin, jossa toimintaa jatkuvasti parannetaan. Vastaavasti englantilaiset ja myös suomalaiset korostavat sitä, että kansainvälisten laatustandardien mukainen toiminta on laatua kehitettäessä tärkeätä. Tämän takia meillä Suomessa on viime vuosina korostettu sitä, että organisaatioiden tulisi hankkia ISO 9000 laatustandardin mukainen hyväksyntä. Muutama koulutusorganisaatiokin on jo tehnyt näin.

\section{Miten toimintaa kehitetään?}

Kongressissa ei esitetty mitään erityistä uutta laadun kehittämismenetelmää. Näyttää siltä, että laatujohtaminen on saavuttanut "kypsän " vaiheen ja toimivat menetelmät jo tunnetaan. Tällä hetkellä kiinnostaa eniten, miten näitä menettelytapoja voidaan soveltaa erilaisissa toimintakonteksteissa.

Oleellista on organisaation toimintojen prosessimainen kuvaaminen ja ydinprosessien joh- taminen niin, että osallistavan yhteistyön avulla saadaan aikaan prosessien jatkuva parantaminen. Johdon tulee osallistua konkreettisesti laatutyöhön. Kehittämistyön ohjantaan ja toiminnan arviointiin voidaan käyttää kansainvälisten laatupalkintojen kriteerejä sekä omien tuotteiden ja palvelujen vertaamista "maailman parhaisiin" tuotteisiin tai palveluihin. Jokaisen työntekijän osallistuminen toteutetaan eri tavoin organisoidun tiimityöskentelyn avulla, jossa sovelletaan $\mathrm{mm}$. laatupiiritoiminnasta tuttuja menetelmiä.

Laadukkaasti toimivassa organisaatiossa tuotteen tai palvelun aikaansaanti nähdään sarjana asiakkaalle arvoa tuottavia toimintoja. Prosessin toteuttajien tulee tietää tarkasti mitä asioita asiakkaat arvostavat. Näin prosessin eri osia ja niihin käytettyä aikaa voidaan tarkastelle kriittisesti ja kysyä: miten paljon tällä vaiheella on asiakkaalle arvoa ja onko arvonlisä suhteessa aikaan joka tähän prosessin vaiheeseen käytetään. Tällä perusteella kaikki turha ja vähäarvoinen karsitaan pois. Tämä ajattelutapa voisi olla käyttökelpoinen myös virastojen ja byrokraattisten organisaatioiden toiminnan tarkasteluun. Näin voitaisiin karsia "turha papereiden pyörittely" ja "poistaa rasvat organisaatiosta".

Osa kongressin esityksistä keskittyikin niiden kokemusten kuvaamiseen, joita on saatu edellä mainittujen menettelytapojen soveltamisen yhteydessä. Keskeinen viesti oli se, että toiminnan yksityiskohdat tulee kehittää yhteistoiminnallisesti työkonteksteissa. Menettelytapojen kritiikitön kopiointi voi johtaa kohtalokkaisiin tai riittämättömiin tuloksiin.

Laatujohtamisen näkökulman edustajat korostavat laatujohtamisen eroavan oleellisesti tulosjohtamisesta. Laatujohtamisessa korostetaan toimintaprosessien jatkuvan parantamisen aikaansaantia toimintaresurssien rationalisoinnin sijasta. Kokemusten mukaan resurssien supistamiset johtavat helpommin palvelujen karsintaan ja laadusta tinkimiseen kuin toiminnan tehokkuuden parantumiseen ja laadun kehittämiseen.

Laatulähtöinen toimintatapa ja jatkuvan kehittämisen aikaansaanti poikkeaa organisaatioiden nykykäytännöistä niin paljon, että sen edellyttää määrätietoista ja pitkäjänteistä koulutus- 
ja kasvatustyötä. Jokaisen on muutettava ajattelu- ja toimintatapojaan.

Seuraavassa arvioin kongressissa esitettyjen ajatusten merkitystä aikuiskoulutuksen näkökulmasta. Kyseessä on tekijän tulkinta, jota ei sellaisenaan esiintynyt missään esitelmässä.

\section{Laadukas toiminta osaamisen kehittämisen näkökulmasta}

Käytän tässä yhteydessä koulutus-käsitteen sijasta käsitettä "osaamisen kehittäminen". Tällä korostan sitä, että organisoitua koulutusta on pidettävä vain yhtenä - joskin tärkeänä osaamisen kehittämisen välineenä. Näin kehittämishaasteet voidaan kiteyttää kahteen kohtaan seuraavasti:

- miten kehitetään koulutusinstituutioita paikkoina, joissa osaamista kehitetään ja - miten kehitetään osaamista organisaatiotoiminnan kontekstissa.

Koulutusinstituutioiden kehittäminen laatujohtamisen näkökulmasta merkitsee sitä, että oppimisprosessia tarkastellaan instituution keskeisimpänä toimintaprosessina. Kaikkia muita prosesseja, kuten hallinnollisia ja talousprosesseja tarkastellaan tälle pääprosessille alisteisina apuprosesseina. Näin esimerkiksi opetusta ja oppitunteja tulisi tarkastella vain yhtenä osana koko tavoiteltavaa oppimisprosessia.

Keskeiseksi kysymykseksi nousee, miten oppimisprosessiin saadaan riittävän konkreettisesti mukaan niiden toimintakontekstien elementtejä, joissa koulutettava joutuu opiskelun jälkeen toimimaan. Esimerkiksi ammatillisessa koulutuksessa tämä merkitsisi sekä työelämän että ajoittaisten työttömyyskausien toimintakontekstien aiempaa määrätietoisempaa huomiointia. Didaktisen ja sisällöllinen kehittämisen on oltava etusijalla hallinnolliseen kehittämiseen nähden.

Oppilaitokset joutuvat toimimaan yhä enemmän liikeyritysten tapaan. Niiden hallinnosta ja taloudesta on siksi karsittava kaikki oppimisen kannalta lisäarvoa tuottamaton toiminta. Tässä työssä voidaan noudattaa pitkälti samoja menetelmiä ja lähtökohtia kuin liiketoimintaprosessien kehittämisessä. Tällöin ei voida välttää edes oppilaitosten olemassaolon perusoletusten kriittistä tarkastelua. Missä määrin koulutusinstituutiot ja perinteisen luokkaoppimisen malli ovat nykylaajuudessa välttämättömiä tai tarpeellisia haluttavan oppimisen aikaansaamiseksi? Onko tilanne erilainen nuorisoasteen näkökulmasta ja toisaalta aikuisopiskelun näkökulmasta?

Asioiden tarkastelua ei tule rajata vain koulutusinstituutioihin. Kokonaisvaltaisen laatujohtamisen toteuttaminen edellyttää osaamisen kehittämisen kysymysten tarkastelua kaikessa organisaatiotoiminnassa. Tällöin oppimista ei tule käsittää vain yksilön oppimisen näkökulmasta. Organisaatiotoiminnan jatkuva kehittäminen edellyttää tiimityöskentelyä ja verkostomaista toimintatapaa. Tämä pakottaa tarkastelemaan oppimista ryhmä- ja organisaatiotasoisena tapahtumakokonaisuutena.

Kokonaisvaltaista laatujohtamisen käsitettä vastaa osaamisen kehittämisen alueella oppivan organisaation käsite. Laatujohtamisen ja oppivan organisaation toimintamalleissa on selviä yhtymäkohtia. Tämä on esimerkki siitä, että meidän kasvatus- ja koulutusalan ihmisten tulisi samanaikaisesti tarkastella eri yhteiskunnan alueilla tapahtuvaa kehitystä. Laatujohtamisen asiantuntijat ovat kiinnostuneita oppimisen ja kasvatuksen kysymyksistä. Meidän aikuiskoulutusihmisten tulisi mielestäni olla vastaavasti kiinnostuneita liikkeenjohdon kysymyksistä mukaanlukien laatujohtaminen. Esimerkiksi koulun kehittämisestä kiinnostuneiden ei tulisi rajoittaa kiinnostustaan vain koulun kehittämishankkeisiin ja niistä kertoviin raportteihin. He voisivat ehkä saada uusia näkökulmia ja virikkeitä hankkimalla asiantuntemusta myös elinkeinoelämän organisaatioiden kehittämisestä ja sen menetelmistä. Näin voimme yhdistää eri alojen asiantuntemusta ja kehittää uusia ratkaisuja organisaation kehittämisongelmiin. 